\title{
Tari Rejang Pala Di Desa Nongan, Kecamatan Rendang, Kabupaten Karangasem: Kajian Bentuk Dan Fungsi
}

\author{
I Wayan Adi Gunarta ${ }^{1}$, Ida Ayu Wayan Arya Satyani ${ }^{2}$ \\ Program Studi Tari, Fakultas Seni Pertunjukan, Institut Seni Indonesia Denpasar \\ Iadie_gunarta@yahoo.com
}

Sejak beberapa tahun terakhir, Rejang mengalami geliat pertumbuhan yang begitu populer. Di tengah suburnya berbagai bentuk tari kreasi rarejangan, di Desa Nongan terdapat tari Rejang yang telah dua kali mengalami rekonstruksi, tahun 1984 dan 2019. Tahun 2019 desa setempat kembali melakukan rekonstruksi merujuk hasil penelitian berjudul Kontinuitas dan Perubahan Tari Rejang Balang Tamak di Desa Nongan, Kecamatan Rendang, Kabupaten Karangasem, tahun 2017. Penulisan artikel ini bertujuan untuk meneliti bentuk dan fungsi Tari Rejang Pala, pasca rekonstruksi tahun 2019. Landasan teoritis yang digunakan adalah teori estetika dan teori fungsional. Model penelitian yang digunakan ialah penelitian kualitatif. Teknik pengumpulan data melalui observasi, wawancara, studi kepustakaan, dan dokumentasi. Hasil penelitian menunjukkan bahwa, Tari Rejang Pala ialah tarian sakral dalam upacara Usaba Desa, untuk menyambut Ida Betara Dalem pada prosesi memasar di Pura Pesamuhan Agung. Para penarinya dibagi dalam tiga klasifikasi umur, yaitu: (1) anak-anak disebut Rejang Alit; (2) remaja putri disebut Rejang Daha; dan (3) Ibu-Ibu disebut Rejang Lingsir. Fungsi primer Tari Rejang Pala, yakni sebagai sarana ritual, secara tidak langsung juga sebagai sarana hiburan pribadi, dan sebagai presentasi estetis. Fungsi sekundernya, sebagai pengikat solidaritas dan sebagai sarana komunikasi. Keunikan Tari Rejang Pala dapat dilihat pada gelungannya, yaitu dihiasi dengan berbagai macam buah-buahan.

Kata Kunci: Tari Rejang Pala, Usaba Desa, Desa Nongan.

\section{Rejang Pala Dance In Nongan Village, Rendang District, Karangasem Regency: Study Of Form And Function}

Since many years ago, Rejang dance is experiencing very popular growth. The midst of the fertility of various forms of rerejangan dance creations, there is a Rejang dance which has been reconstructed twice in the Nongan village in 1984 and 2019. In 2019 the local village reconstructed again referring to the results of a study entitled Continuity and Changes in the Revised Balang Tamak Dance in Nongan Village, Rendang District, Karangasem Regency in 2017. The purpose of this study is for knowing the shape and the function of the Rejang Pala dance after reconstruction in 2019. The theories were used aesthetic theory and functional theory. The method was used in this study was the qualitative method. The technic in collecting the data used observation, interview, library study, and documentation. The result of this study showed that Rejang Pala dance as a sacred dance that had a religious value which was showed in Usaba Desa in welcoming Ida Betara Dalem in memasar procession in Pesamuan Agung temple. The dancers are divided into three age classifications, those are (1) young girls called Rejang Alit; (2) Teenager called Rejang Daha; (3) the mothers called Rejang Lingsir. The primer functions of Rejang Pala dance are as a ritual and indirectly as personal entertainment also as an aesthetic presentation. Even though, the secondary functions are binding of solidarity and as a communication tool. The uniqueness of the Rejang Pala dance can be seen from the Gelungan which are decorated with various kinds of fruits.

Keywords:Rejang Pala dance, Usaba Desa, Nongan village.

Proses Review : 1 - 20 Mei 2020, Dinyatakan Lolos: 29 Mei 2020 


\section{PENDAHULUAN}

Di Bali, setiap pelaksanaan upacara keagamaan Hindu (puja wali), khususnya upacara Dewa Yadnya, selalu identik dengan dipentaskannya tari wali, salah satunya ialah tari Rejang. Bandem dan Fredrik Eugene deBoer memaparkan bahwa, Rejang adalah salah satu pertunjukan yang kuno, formal, memiliki wibawa dan elegansi, serta ciri khas yang sangat menawan. Rejang merupakan tarian prosesional yang dipertunjukkan oleh wanita anggota jemaah pura. Semuanya memakai pakaian formal tradisional Bali, dengan selendang (anteng) panjang yang diikatkan di pinggangnya, dan hiasan semi melingkar di kepala yang terdiri dari kerangka emas dan dihiasi bunga segar (2004: 22-23). Sebagai sebuah pertunjukan yang bersifat religius, bentuk koreografi tari Rejang sangatlah sederhana. Jumlah penari Rejang bisa mencapai puluhan, mereka menari dalam formasi berbaris maupun melingkar mengelilingi areal pura.

Sejak beberapa tahun terakhir, Rejang tengah mengalami geliat pertumbuhan yang begitu populer dalam kehidupan seni, sosial, dan religius masyarakat Hindu Bali, khususnya di kalangan perempuan. Berbagai bentuk tari Rejang terus bermunculan menghiasi jagat seni pertunjukan Bali seperti; Tari Rejang Pakuluh yang diciptakan oleh Ni Komang Sri Wahyuni tahun 2016, Tari Rejang Sari yang diciptakan oleh I Ketut Rena tahun 2017, Tari Rejang Santhi yang diciptakan oleh Ida Ayu Wayan Arya Satyani dan digagas oleh Bulantrisna Jelantik tahun 2017, Tari Rejang Sandat Ratu Segara diciptakan oleh I Wayan Juana Adi Saputra tahun 2018, dan yang paling fenomenal adalah Tari Rejang Renteng karya Ida Ayu Made Diastini bersama Dinas Kebudayaan Provinsi Bali, yang belakangan ini (mulai sekitar tahun 2016-an hingga sekarang) begitu populer dan dipentaskan hampir di seluruh Bali dalam setiap gelaran pelaksanaan upacara.

Fenomena kemunculan berbagai macam bentuk tari Rejang, nampaknya menjadi semacam trend yang sedang menancapkan pilar-pilar eksistensinya di tengah arus modernisasi global. Terlebih lagi pada gelaran pelaksanaan Pesta Kesenian Bali (PKB) Ke- 40 Tahun 2018, tari kreasi rarejangan menjadi salah satu materi pentas yang wajib dibawakan dalam Parade Gong Kebyar Anak-Anak, yang diikuti oleh Sekaa Gong Anak-Anak perwakilan dari sembilan kabupaten/kota dan provinsi se-Bali. Kurang lebih ada sepuluh bentuk tari Rejang baru atau kreasi rarejangan yang dibawakan oleh masing-masing peserta pada acara Parade Gong Kebyar Anak-Anak, di antaranya; Tari Rejang Padupan Duta Kabupaten Badung karya I Gede Parwata dan Ni Gusti Ayu Priyanti, Tari Rejang Pratita Duta Kota Denpasar karya Ni Kadek Diah Pramanasari dan I Wayan Yudi Setiadi, Tari Rejang Bebayuhan Duta Kabupaten Gianyar karya Ni Kadek Sudarmanti, serta Tari Rejang Tirta Duta Provinsi Bali. Melihat realitas perkembangan Rejang yang fenomenal dalam kehidupan budaya religius masyarakat Hindu Bali, tentunya tidaklah berlebihan jika penulis menyebutnya dengan istilah "Demam Ngerejang".

Di tengah-tengah bertumbuh suburnya berbagai bentuk tari Rejang baru atau kreasi rarejangan, pada bulan April 2019 di Desa Nongan, Kecamatan Rendang, Kabupaten Karangasem, Bali, dipentaskan sebuah bentuk tari Rejang yang merupakan hasil rekonstruksi, yaitu Tari Rejang Pala. Ketika itu, penulis berkesempatan hadir secara langsung untuk menyaksikan pertunjukan Tari Rejang Pala, yang disambut dengan penuh antusias oleh masyarakat. Tari Rejang Pala merupakan sebuah tarian sakral warisan Pura Balang Tamak yang kini juga dipentaskan dalam gelaran upacara Usaba Desa di Pura Pesamuhan Agung, Desa Nongan. Tarian ini ditarikan oleh para penari perempuan dengan tiga klasifikasi umur (tiga generasi) yang berbeda, mulai dari: (1) anak-anak perempuan; (2) daha (remaja putri); dan (3) Ibu-Ibu. Gerakan tarinya menggunakan gerak-gerak sederhana bernuansa ritual, khas rarejangan. Dibia mengatakan bahwa, Tari Rejang adalah sebuah tarian yang memiliki gerak-gerak tari yang sederhana dan lemah gemulai, dibawakan oleh penari-penari putri (pilihan maupun campuran dari berbagai usia) yang dilakukan secara berkelompok atau masal (1999:10). Keunikan dari Tari Rejang Pala dapat dilihat pada gelungan (hiasan kepala) yang digunakan oleh para penari Rejang dari kelompok daha (remaja putri), yakni dihiasi dengan berbagai jenis buah-buahan segar hasil perkebunan masyarakat setempat. Begitu pula pada penari Rejang kelompok anak-anak, pada bagian kepalanya juga mempergunakan hiasan kepala semacam gelungan, yang juga dihiasi dengan buah-buahan. Sedangkan untuk penari kelompok ibu-ibu hiasan kepalanya menggunakan Sanggul Bali dan semanggi dari buah-buahan, serta membawa bokoran berisi canang sari (sesaji) yang di atasnya diisi beberapa jenis buah. Berdasarkan uraian di atas, penelitian ini bertujuan untuk mengkaji secara mendalam mengenai bentuk dan fungsi dari Tari Rejang Pala di Desa Nongan, yang merupakan hasil rekonstruksi pada tahun 2019. Rekonstruksi tersebut dilakukan atas dasar hasil penelitian berjudul Kontinuitas dan Perubahan Tari Rejang Balang Tamak di Desa Nongan, Kecamatan Rendang, Kabupaten Karangasem, tahun 2017.

\section{METODE PENELITIAN}

Merujuk pada fokus masalah dalam penelitian ini adalah bentuk dan fungsi pada Tari Rejang Pala, maka teori yang dipandang dapat menjadi pisau bedah adalah teori estetika yang dikemukakan oleh Djelantik dan teori fungsional oleh Soedarsono. Adapun dalam operasionalnya menggunakan metoda penelitian kualitatif, yaitu penelitian yang bermaksud untuk memahami fenomena tentang apa yang dialami oleh subjek penelitian misalnya perilaku, persepsi, motivasi, tindakan, dan lainnya, secara holistik dengan cara deskripsi dalam bentuk kata-kata dan bahasa, pada 
suatu konteks khusus yang alamiah dengan memanfaatkan berbagai metode alamiah (Moleong, 2011: 6). Jenis data yang digunakan, yaitu data primer dan data sekunder. Sumber data primer dalam penelitian ini ialah pementasan Tari Rejang Pala dan informasi atau keterangan secara lisan yang didapatkan langsung dari informan kunci. Sedangkan data sekunder didapatkan melalui referensi tertulis berupa buku dan jurnal yang digunakan sebagai rujukan untuk memperkuat analisis data.

Proses pengumpulan data penelitian dilakukan melalui teknik: 1) Observasi, pengamatan secara langsung atas Tari Rejang Pala dimulai sejak proses rekonstruksi tarian ini dilaksanakan pada bulan Maret 2019 dan observasi terus berlanjut hingga pementasan perdana atau makebah dilaksanakan pada bulan April 2019, dimana penulis terlibat di dalamnya sebagai tim rekonstuksi. Dalam hal ini, penulis terlibat dan dapat mengamati secara langsung Tari Rejang Pala, mulai dari proses latihan atau mempersiapkan penari, persiapan sarana dan prasarana pementasan maupun upacara yang dilakukan oleh masyarakat desa, dan menonton pementasan Tari Rejang Pala dalam upacara Usaba Desa; 2) Wawancara, mengumpulkan data-data lisan berupa keterangan dari para informan utama yang telah terpilih; 3) Studi kepustakaan, yakni mengumpulkan sumber-sumber tertulis yang terkait dengan topik penelitian, guna memperkuat hasil analisis data penelitian; 4) Dokumentasi, mengumpulkan data-data penunjang berupa foto maupun video Tari Rejang Pala. Data-data penelitian yang telah dikumpulkan selanjutnya dideskripsikan, dianalisis, dan disusun secara sistematis, hingga akhirnya ditarik suatu kesimpulan.

\section{ANALISIS DAN INTERPRETASI DATA}

"Wujud" dalam karya seni merupakan sesuatu yang dapat dinikmati oleh penikmat dan mempunyai dua unsur utama, yakni bentuk (form) dan susunan (structure) (Djelantik, 1990: 14). Bentuk atau unsur internal sebuah pementasan tari, dapat dilihat dari beberapa elemen yang dapat dinikmati dan ditangkap oleh panca indra, yaitu ragam gerak, pola lantai, penari, tata rias dan tata busana, musik iringan tari, serta tempat pementasan. Secara terperinci bentuk pementasan Tari Rejang Pala dapat dijelasakan sebagai berikut.

\section{Bentuk Tari Rejang Pala}

Setiap Purnama kaulu (bulan purnama ke-8 dalam perhitungan kalender Bali/tahun caka), di Pura Balang Tamak, Desa Nongan, Kecamatan Rendang, Kabupaten Karangasem digelar upacara (piodalan) yang disebut Usaba Pala. Upacara ini merupakan bentuk ungkapan rasa syukur kepada Dewi Sri atas keberhasilan panen. Hal ini tentunya tidak terlepas dari fungsi Pura Balang Tamak sebagai Pura Ulun Suwi atau Pura Subak dan menjadi pusat (hulu) dari subak-subak kecil (subak abian) yang ada disekitarnya. Masyarakat setempat meyakini bahwa, dahulunya Tari
Rejang Pala selalu dipentaskan pada upacara Usaba Pala. Namun demikian, sempat terjadi kevakuman karena terputusnya proses regenerasi penari yang mengakibatkan kehilangan jejak koreografinya. Jejak yang ditinggalkan hanya berupa gelungan (hiasan kepala) rejang berisi sedikit buah dan bunga, ditempatkan di dalam bodag (kotak besar terbuat dari anyaman bambu) sejumlah 11 buah, yang diletakkan di Bale Pasamuhan (bangunan berbentuk persegi empat) tempat meletakkan pretima Jero Gede Balang Tamak selama upacara berlangsung. Sesungguhnya, Rejang Pala di Pura Balang Tamak pernah direkonstruksi pada tahun 1984 (Satyani, 2018: 2-5). Akan tetapi eksistensi atau keberlangsungannya kembali menemui kemandekan. Akhirnya pada tahun 2019, prajuru Desa Adat Nongan (Bendesa Adat: I Gusti Ngurah Wiryanata) dan Kepala Desa Nongan (Perbekel: I Wayan Daging) beserta seluruh elemen masyarakat Desa Nongan berinisiatif untuk merekonstruksi atau nangiang (membangunkan kembali) Tari Rejang Pala, sebagai sebuah bentuk usaha pelestarian warisan budaya daerah. Tari Rejang Pala yang awalnya hanya ditarikan di Pura Balang Tamak serangkaian piodalan (dulu disebut Usaba Pala), sejak rekonstruksi ini juga ditarikan serangkaian upacara Usaba Desa di Pura Pasamuhan Agung, dengan demikian kelestarian Rejang ini tidak saja menjadi tanggung jawab pangempon Pura Balang Tamak melainkan menjadi tanggung jawab masyarakat bersama diayomi oleh desa setempat. Perlu disampaikan bahwa Desa Nongan menaungi tiga belas banjar, dan pura Balang Tamak terletak di Banjar Nongan Kaler.

Rekonstruksi adalah usaha untuk menyusun kembali suatu objek tertentu yang dahulunya pernah ada, namun kini keberadaannya telah hancur, hilang, ataupun mengalami kerusakan, agar wujudnya dapat dikembalikan seperti keadaan semula. Proses rekonstruksi harus dilakukan berdasarkan hasil riset, yakni berupa kumpulan berbagai bentuk data faktual atas objek yang hendak direkonstruksi. Dalam konteks merekonstruksi tari, hasil penggalian data-data tersebut bisa berupa pola-pola gerak tari, artefak berupa kostum maupun gelungan, notasi musik iringan tari atau musik pengiring, referensi tertulis, kesaksian atau keterangan dari informan/narasumber, foto, video, dan lain sebagainya. Semua itu dapat dijadikan sebagai acuan atau sumber rujukan untuk merekonstruksi suatu bentuk tarian. Dengan demikian, harapannya adalah agar nantinya keabsahan dari sebuah hasil rekonstruksi dapat dipertanggung jawabkan.

Tari Rejang Pala yang ada di Desa Nongan, Kecamatan Rendang, Kabupaten Karangasem direkonstruksi oleh Ida Ayu Wayan Arya Satyani dan I Gusti Ngurah Sudibya. Setelah melalui proses pengumpulan data dan proses rekonstruksi yang panjang, Tari Rejang Pala pun berhasil diwujudkan dan untuk pertama kalinya Makebah atau dipentaskan pada tanggal 8 April 2019 dalam upacara Usaba Desa di Pura Pesamuhan Agung Desa Nongan. Usaba Desa merupakan sebuah upacara (Dewa Yadnya) yang di- 
gelar oleh masyarakat Desa Nongan setiap satu tahun sekali, tepatnya pada pinanggal kaping 3 (tiga) sasih jiyestha (hari ketiga setelah tilem/bulan mati sasih kadasa dalam perhitungan kalender Bali/tahun caka), untuk menyambut (mamendak) Ida Betara Dalem pada prosesi memasar atau paruman di Pura Pesamuhan Agung. Desa Nongan memiliki dua pura dalem, yaitu Pura Dalem Kupa bertempat di bagian utara desa dan Pura Dalem Nongan bertempat di bagian selatan. Pada prosesi mendak Ida Batara Dalem Kupa maupun Batara Dalem Nongan, Rejang Pala ditarikan dari Pura Balang Tamak (di Utara) dan Bale Pegat (di Selatan) kemudian berjalan dibarisan paling depan dan bertemu di Pura Pasamuhan Agung tempat disthanakannya Ida Batara Dalem selama Usaba Desa. Usaba Desa berlangsung tiga hari, sepanjang itu pula Rejang Pala ditarikan sebagai bagian dari upacara.

Tari Rejang Pala ialah sebuah tarian sakral bernilai religius yang ditarikan secara berkelompok oleh para penari perempuan. Pada pementasan perdana (makebah), tepatnya pada pucak upacara mamasar, tarian ini melibatkan lebih dari 150 orang penari yang terdiri dari; anak-anak perempuan yang belum akil balik disebut Rejang Alit, daha atau remaja putri disebut Rejang Daha, dan ibu-ibu disebut $R e$ jang Lingsir. Dalam pementasannya, para penari Rejang Pala menari dalam formasi 4 (empat) baris berbanjar di sepanjang Marga Agung atau jalan raya Nongan-Besakih yang posisinya berada di depan Pura Pesamuhan Agung. Para penari Rejang Alit berada pada barisan paling depan, kemudian dilanjutkan dengan penari Rejang Daha, dan terakhir ditutup oleh para penari Rejang Lingsir. Setiap kelompok penari, menari dengan pola gerak (koreografi) yang berbeda sesuai dengan karakternya masing-masing. Namun semuanya tetap terpadu menjadi satu kesatuan bentuk tari yang utuh. Untuk mendapatkan gambaran secara lebih jelas, bentuk formasi dan urutan barisan dari para penari Rejang Pala dapat digambar seperti berikut.

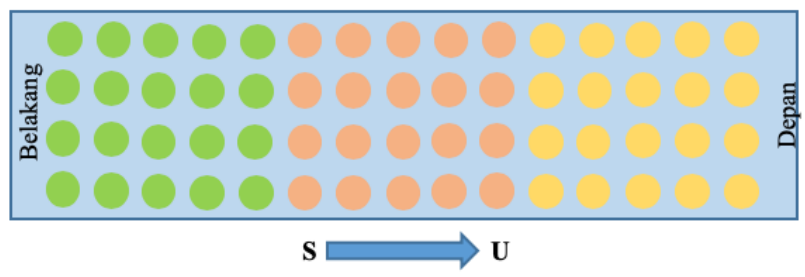

Gambar 1. Ilustrasi gambar formasi penari Rejang Pala

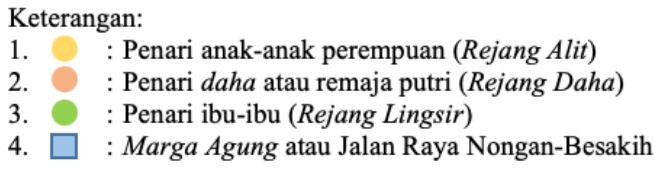

Struktur Tari Rejang Pala terdiri dari empat bagian, yaitu Mataki-taki, Masolah, Makideh/Pakideh, dan Panyawis. Mataki-taki merupakan adegan awal yang dimulai ketika seluruh penari atau pregina rejang bersiap berbaris sesuai kelompoknya, sampai dengan gending (musik tari) ditabuh, dimana pada bagian awal gending, pregina rejang

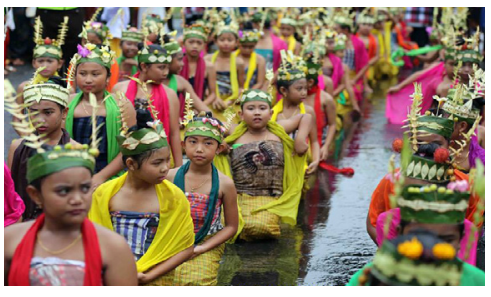

Gambar 2. Pementasan Tari Rejang Pala (tampak penari Rejang Alit duduk bersimpuh) dalam upacara Usaba Desa di Pura Pesamuhan Agung, Desa Nongan, Karangasem (Foto: Ketut Parwatha Wijaya, 2019)

(khususnya Rejang Daha) menggerakkan tangan kanan perlahan ke belakang diikuti kepala menoleh ke belakang ke arah penari di belakangnya, untuk memastikan kesiapan seluruh penari serta merapihkan barisan. Setelah itu dilanjutkan dengan Masolah, setiap kelompok pragina rejang menarikan bagian inti koreografinya masing-masing. Rejang Alit menari dengan gerakan-gerakan yang sangat sederhana. Mereka menari sembari mengibas-ngibaskan selendang ke depan dan ke belakang secara berulang, kemudian menghempaskan selendang ke samping kanan dan ke samping kiri, serta sesekali diselingi dengan gerakan tangan mentang (tangan direntangkan ke samping kanan dan kiri). Seluruh gerakan dilakukan dengan ekspresi kanak-kanak yang alami. Jenis selendang yang digunakan oleh penari Rejang Alit ialah kain sejenis sifon yang warnanya beraneka ragam, dikalungkan dileher sehingga kedua ujungnya menjuntai ke arah kaki. Selanjutnya pada bagian Makideh/Pakideh mereka menari dan saling bertukar tempat dari kanan ke kiri, secara bergantian dan berulang-ulang sebanyak 3 kali putaran, sambil meneriakan kata "Suryaaakk..." dan "Kasiiiiih..."dengan nada lantang saling bersahutan, hingga diakhiri dengan posisi duduk bersimpuh menghadap ke penari Rejang Daha.

Untuk penari Rejang Daha, pada bagian Masolah, mereka menari dengan pola-pola gerak yang sangat anggun. Dengan posisi kepala yang sedikit menengadah, Rejang Daha mulai menggerakkan tangan kanannya seakan mengusap daerah telinga yang dihiasi anting-anting dari buah (menyerupai prekapat/hiasan pada bagian samping gelungan), diistilahkan dengan gerakan ngarna. Gerakan tangan ini berlanjut diputar di depan dada dan berakhir di daerah pinggul dengan posisi telapak tangan menghadap ke bawah. Kemudian dilanjutkan dengan gerakan memutar pinggul setengah lingkaran, gerakan tangan mentang dan melentikkan jari, ngotes, hingga ngingsak. Gerakan tersebut dilakukan berulang-ulang sampai empat kali putaran kanan dan kiri. Kemudian masuk ke bagian Makideh/ Pakideh para penari Rejang Daha menari dan bergerak membentuk huruf ' $S$ ' atau seperti ular naga yang saling bersambungan, dimulai dari bagian ekor menjadi barisan paling depan hingga kembali ke posisi barisan semula. Penari daha juga menggunakan selendang berwarna-warni yang diikatkan pada bagian pinggang. 


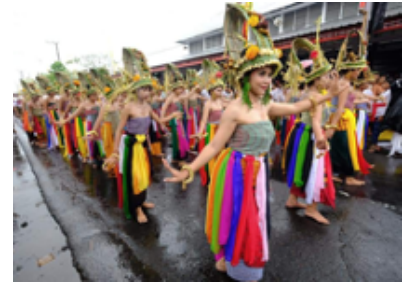

Gambar 3. Pementasan Tari Rejang Pala (tampak Penari Rejang Daha) dalam upacara Usaba Desa, di Pura Pesamuhan Agung, Desa Nongan, Karangasem (Foto: Komang Manksu, 2019)

Adapun untuk penari Rejang Lingsir, pada bagian Masolah mereka menari merentangkan tangan kiri sembari mengambil selendang yang diikatkan di pinggang, dengan posisi tangan kanan ngagem sambil memegang bokoran yang berisi canang sari. Dilanjutkan dengan gerakan ulapulap, soyor ngawan (rebah kanan) dan soyor ngebot (rebah kiri), kemudian berjalan maju dan mundur, masing-masing dilakukan dalam 4 hitungan. Kemudian dilanjutkan dengan gerakan ngegol menghadap keempat penjuru arah mata angin, secara berturut-turut dimulai dengan menghadap ke depan/utara, samping kanan/timur, belakang/ selatan, samping kiri/barat, hingga kembali menghadap ke depan. Gerakan ngegol pada masing-masing arah mata angin dilakukan dalam 8 hitungan. Pada bagian Makideh/ Pakideh, penari Rejang Lingsir berada dalam posisi berdiri dengan kedua tangan memegang bokoran di depan dada, sambil menyanyikan syair lagu sebagai berikut.

$\begin{array}{lll}\text { Bait 1: } & \text { Bait 2: } & \text { Bait 3: } \\ \text { Kelad kelid } & \text { Malincer-lincer } & \text { Tepuk lepas } \\ \text { Kaja kelod } & \text { Mangider-ider } & \text { Jemak pundu- } \\ \text { Kangin kauh } & \text { Srandang-srendeng } & \text { hang } \\ \text { Menek tuun } & \text { Gumatat gumitit } & \text { Uli dija dewa } \\ \text { Rama rena } & \text { Dapdap tis } & \text { madewi } \\ & & \text { Amun lali } \\ & & \text { Kutang lisik } \\ & & \text { jemak margi } \\ & & \text { Ngareronce } \\ & & \text { Nyom ai ne }\end{array}$

Dalam posisi tersebut, penari Rejang Lingsir menyanyikan syair lagu dengan penuh rasa hikmad, sebagai sebuah ungkapan doa. Pada bagian Makideh/Pakideh ini, Rejang Lingsir berputar menghadap ke empat arah mata angin sesuai posisi mereka berdiri, kemudian bergeser ke samping kanan (berputar seolah-olah membentuk padma atau pusaran) setiap kali nyanyian yang dilantunkan bertemu kata "malincer-lincer, maider-ider". Nyanyian terus dilantunkan berulang-ulang sambil menunggu rejang daha menyelesaikan adegan pakideh. Setelah adegan Makideh di Marga Agung selesai, seluruh penari Rejang Pala (Rejang Alit, Rejang Daha, Rejang Lingsir) kembali menari membentuk satu barisan seperti posisi awal, secara satu persatu bergerak memasuki jaba pura (halaman depan pura) secara berkesinambungan, mulai dari Rejang Alit, kemudian

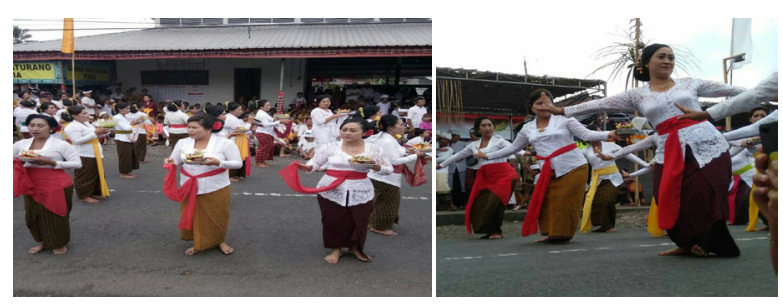

Gambar 4. Pementasan Tari Rejang Pala (tampak Penari Rejang Lingsir) dalam upacara Usaba Desa, di Pura Pesamuhan Agung, Desa Nongan, Karangasem (Foto: Ketut Parwatha Wijaya, 2019)

dilanjutkan oleh Rejang Daha, dan diakhiri oleh penari Rejang Lingsir. Pada bagian ini, penari Rejang Daha secara khusus melanjutkan makideh (berputar mengelilingi pelinggih atau bangunan suci) di Jeroan Pura (halaman utama pura) sebanyak 3 kali putaran. Ketika Rejang Daha telah menyelesaikan putaran makideh sebanyak 3 kali di jeroan pura, maka tarian pun memasuki bagian panyawis dan diakhiri dengan persembahyangan bersama.

Jika diperhatikan dengan seksama, struktur Tari Rejang Pala ini memperlihatkan sebuah jalinan harmoni gerak yang begitu indah. Meskipun gerak-gerak tarinya sangat sederhana dan masing-masing kelompok penari juga memiliki pola gerak yang berbeda-beda, namun semuanya itu terlihat melebur dalam satu kesatuan rangkaian gerak estetis yang saling terkait satu sama lain, serta mampu memberikan kesan bagi siapapun yang melihatnya. Kekhasan dari Tari Rejang Pala dapat dilihat pada gelungan atau hiasan kepala yang digunakan oleh para penari, yakni dihiasi dengan berbagai macam buah-buahan seperti rambutan, salak, jeruk, ceroring, kepundung, boni, dan lain sebagainya. Tarian ini disebut Rejang Pala karena dahulunya dipentaskan dalam rangkaian upacara Usaba Pala di Pura Balang Tamak, Desa Nongan, Karangasem. Mengingat Usaba Pala merupakan sebuah upacara yang ditujukan kepada dewa-dewi sebagai bentuk ungkapan rasa puji syukur atas keberhasilan panen, baik itu di sawah (menghasilkan padi) maupun di ladang (menghasilkan buah-buahan). Selain itu tentunya juga tidak terlepas dari penggunaan buah-buahan sebagai bahan untuk hiasan gelungan Rejang. Dalam bahasa Bali-nya buah juga disebut pala, sehingga tarian sakral ini kemudian dikenal oleh masyarakat Desa Nongan sebagai Tari Rejang Pala.

\section{Penari Tari Rejang Pala}

Penari atau dalam bahasa Bali disebut pragina merupakan pelaku utama dari sebuah pementasan tari. Tari Rejang Pala ditarikan oleh para penari perempuan dengan tiga klasifikasi umur yang berbeda, yaitu: (1) anak-anak perempuan disebut Rejang Alit; (2) daha (remaja putri) disebut Rejang Daha; dan (3) Ibu-Ibu disebut Rejang Lingsir. Secara filosofis, Rejang Alit merepresentasikan masa yang akan datang (nagata), Rejang Daha merepresentasikan masa sekarang (wartamana, masa yang rentan yang harus dijaga disetiap tindak tanduknya), dan Rejang Lingsir 

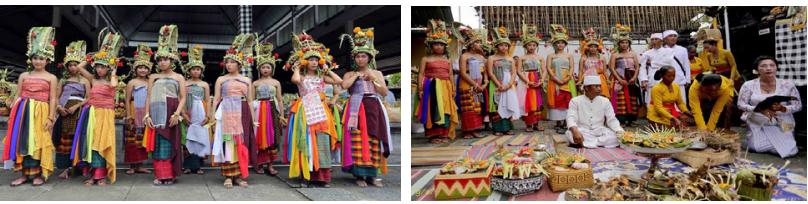

Gambar 5. Penari inti Tari Rejang Pala sejumlah 11 orang (tampak penari Rejang Daha pada foto kanan dan kiri) saat prosesi ngaturang pamendak pada Ida Betara Dalem dalam upacara Usaba Desa di Pura Pesamuhan Agung, Desa Nongan, Karangasem (Foto: Ketut Parwatha Wijaya, 2019)

merepresentasikan masa lampau (atita, masa yang menjadi akar pijak, penguat, sebagaimana ibu, pertiwi).

Adapun jumlah penari yang terlibat dalam pementasan perdana Tari Rejang Pala pada upacara Usaba Desa dapat dijelaskan sebagai berikut. Awalnya dalam rangka pementasan perdana (makebah) tersebut, Bendesa Adat Nongan memberi hitungan jumlah penari keseluruhan adalah 150 orang, dengan rincian: 70 orang penari Rejang Daha, 40 orang Penari Rejang Alit, dan 40 orang penari Rejang Lingsir. Dalam realisasinya saat pementasan Tari Rejang Pala berlangsung, jumlah penari yang terlibat atau berkumpul untuk masing-masing kelompok rejang mencapai angka 70 s/d 80 orang. Semua itu terjadi karena tingginya antusias dan rasa bakti masyarakat Desa Nongan untuk ikut terlibat ngayah menarikan Tari Rejang Pala pada upacara Usaba Desa. Para penari Rejang Pala tersebut merupakan representasi masyarakat dari 13 banjar yang ada di Desa Nongan. Akan tetapi jika merujuk pada jumlah gelungan rejang yang masih diwariskan di Pura Balang Tamak, maka jumlah penari inti Rejang Pala adalah 11 orang dan semuanya berasal dari kelompok Rejang Daha. Selain itu, untuk bisa ikut ngayah menarikan Tari Rejang Pala juga ada syaratnya, yakni khususnya bagi para penari Rejang Daha dan Rejang Lingsir ialah tidak sedang mengalami cuntaka (keadaan tidak suci menurut pandangan agama Hindu, seperti sedang mengalami datang bulan atau kematian keluarga dekat).

\section{Tata Rias dan Tata Busana Tari Rejang Pala}

Tata rias dan tata busana merupakan unsur penunjang yang mendukung kesuksesan sebuah pementasan tari, serta berperanan penting dalam mewujudkan visualisasi tari yang estetis. Penggunaan tata rias dalam pementasan tari berfungsi untuk memperindah wajah penari, memperkuat ekspresi, dan memperjelas tokoh yang diperankan. Sedangkan tata busana atau kostum tari berfungsi untuk memperindah dan memperkuat gerak-gerak tari yang dilakukan oleh penari. Pada prinsipnya kostum tari harus terasa nyaman ketika digunakan, tidak mengganggu pergerakan atau pun menutupi desain-desain gerak yang muncul dari tubuh penari. Pada pementasan Tari Rejang Pala dalam upacara Usaba Desa di Desa Nongan, tata rias wajah yang digunakan oleh kelompok penari Rejang Alit, Rejang Daha, dan Rejang Lingsir ialah bersifat korektif, yakni untuk mempertegas garis-garis wajah agar terlihat

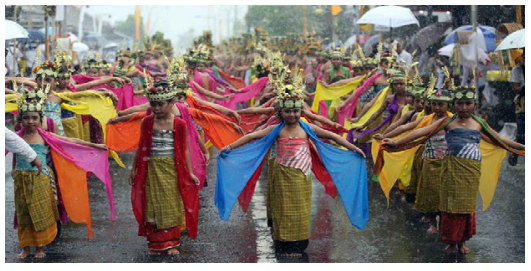

Gambar 6. Tata rias dan Busana Tari Rejang Pala (Rejang Alit) dalam upacara Usaba Desa di Pura Pesamuhan Agung, Desa Nongan, Karangasem (Foto: Ketut Parwatha Wijaya, 2019)

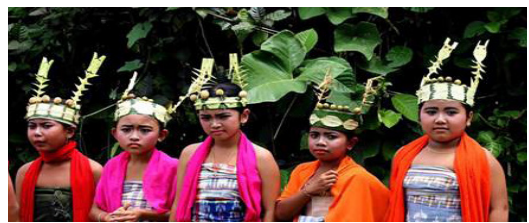

Gambar 7. Hiasan kepala Tari Rejang Pala (Rejang Alit) Foto: Ketut Parwatha Wijaya, 2019

lebih segar. Visual yang ditampilkan lebih menonjolkan pada kesan wajah yang alami atau natural. Dalam pementasan tersebut, setiap kelompok penari mampu menampilkan kekuatan ekspresi sesuai dengan karakternya masing-masing. Sedangkan untuk tata busana yang digunakan oleh masing-masing kelompok pragina rejang dalam pementasan Tari Rejang Pala dapat diuraikan sebagai berikut.

Tata busana tari yang digunakan oleh penari Rejang Alit terdiri: tapih dan kain (kamen) sebagai penutup bagian kaki, selendang blengket yang dililitkan di badan, selendang kain warna-warni dikalungkan pada leher, dan menggunakan hiasan kepala yang terbuat dari rangkaian janur (busung) dan daun pohon aren (ron). Hiasan kepala Rejang Alit dihiasi dengan buah-buahan seperti kepundung dan boni, serta untuk memperindah tampilannya juga dihiasi dengan beberapa kuntum bunga seperti bunga kamboja, bunga merak, maupun bunga gumitir.

Untuk penari Rejang Daha, tata busana yang digunakan terdiri dari: tapih dan kain (kamen) digunakan sebagai penutup tubuh bagian bawah atau kaki, selendang blengket dililitkan pada bagian badan, beberapa lembar selendang kain berwarna-warni yang diikatkan pada bagian pinggang, gelang tangan yang terbuat dari buah-buahan, dan menggunakan gelungan atau hiasan kepala. Gelungan penari Rejang Daha untuk kerangkanya terbuat dari rangkaian bambu. Kemudian dihiasi dengan rangkaian janur (busung) dan daun pohon aren (ron), serta dihiasi dengan berbagai jenis buah seperti salak, rambutan, kepundung, boni, dan juga diperindah dengan memasangkan beberapa kuntum bunga seperti bunga gumitir, bunga merak, maupun bunga pucuk (kembang sepatu).

Terkahir, untuk penari Rejang Lingsir menggunakan tata busana yang terdiri dari: kain (kamen) yang digunakan untuk menutupi bagian kaki, baju kebaya warna putih, selendang kain berwarna-warni yang diikatkan di pinggang, 


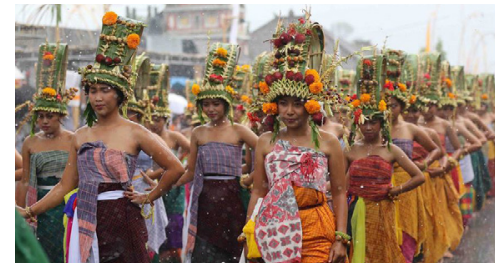

Gambar 8. Tata riasdan Busana Tari Rejang Pala (Rejang Daha) dalam upacara Usaba Desa di Pura Pesamuhan Agung, Desa Nongan, Karangasem (Foto: Ketut Parwatha Wijaya, 2019)

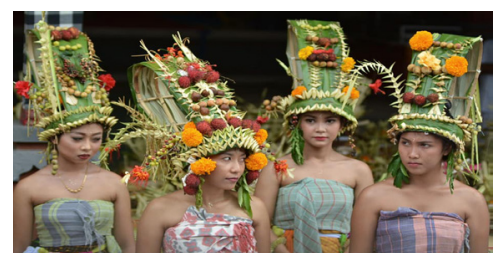

Gambar 9. Gelungan (hiasan kepala) Tari Rejang Pala (Rejang Daha) yang dihiasi dengan buah-buahan Foto: Nyoman Suparta, 2019

dan subeng (hiasan telinga). Sedangkan untuk bagian kepalanya menggunakan Sanggul Bali serta dihiasi dengan buah kepundung dan bunga mawar. Selain itu, penari Rejang Lingsir juga membawa bokoran yang berisi sesaji berupa canang sari dan buah-buahan.

\section{Musik Tari Rejang Pala}

Musik tari merupakan salah satu elemen penting yang keberadaannya dapat menunjang keberhasilan sebuah pementasan tari, karena dapat membantu mempertegas aksen-aksen gerak tari dan memperkuat suasana pertunjukan sehingga 'roh' dan energi dari pementasan tari semakin dapat dirasakan oleh penikmatnya. Pementasan Tari Rejang Pala dalam upacara Usaba Desa di Desa Nongan diiringi dengan Gambelan Gambang, dengan pertimbangan bahwa Gambang termasuk salah satu gamelan kuna dan tercatat dalam salah satu bait kakawin Mayantaka mengenai Gambang dan Rejang. Meskipun koreografi masing-masing kelompok Rejang dibuat berbeda, namun gending gamelan yang digunakan sama. Penggunaan instrumen musik gambang mampu menghadirkan nuansa klasik dan religius selama pementasan berlangsung. Alunan melodi Gambelan Gambang yang mengalir dengan merdu, melebur harmonis dengan irama gerak para penari Rejang Pala yang lemah gemulai, sehingga semakin memperkuat suasana kesakralan pementasan pada upacara Usaba Desa. Musik Tari Rejang Pala dikomposisikan oleh Mangku Dalang Yoganata, dengan jumlah penabuh 4 orang.

\section{Tempat Pementasan Tari Rejang Pala}

Di Bali, tempat yang digunakan untuk mementaskan pertunjukan, khususnya tari disebut dengan kalangan. Kalangan atau arena pertunjukan ini sifatnya tidak permanen, dapat dibuat dimana saja sesuai dengan kebutuhan dan konteks pementasan, seperti misalnya; menggunakan areal

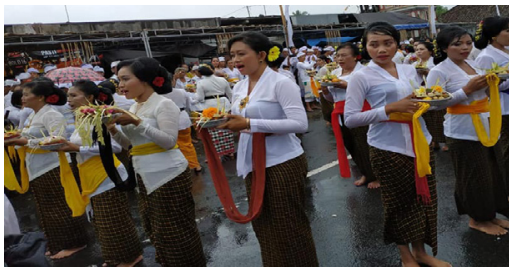

Gambar 10. Tata rias dan Busana Tari Rejang Pala (Rejang Lingsir) dalam upacara Usaba Desa di Pura Pesamuhan Agung, Desa Nongan, Karangasem (Foto: Sinaryati, 2019)

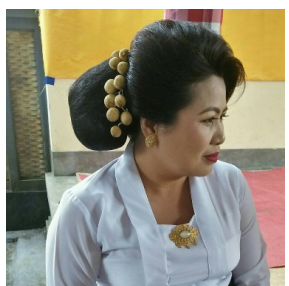

Gambar 11. Hiasan bagian kepala Tari Rejang Pala (Rejang Lingsir) menggunakan Sanggul Bali dan buah kepundung

(Foto: Widiasih, 2019)

halaman (lapangan yang luas), jalan, halaman pura, kuburan, di bawah pohon beringin, dan lain sebagainya. Tari Rejang Pala sebagai suatu bentuk tarian sakral tentunya tidak dapat dipentaskan di sembarang tempat. Dapat dipaparkan bahwa, tari sakral indikasi tempat pementasannya biasanya dilakukan di jeoran pura (halaman utama pura), yang oleh masyarakat Hindu Bali dianggap sebagai bagian yang paling suci atau bisa juga letak pementasanya berada dekat dengan tempat sesaji maupun tempat pendeta melakukan pemujaan. Akan tetapi, ada kalanya semua itu bisa disesuaikan kembali berdasarkan desa (tempat), kala (waktu), patra (keadaan), dan kebutuhan atau pertimbangan kapasitas ruang yang diperlukan untuk pementasan. Mengingat dalam konsepsi Hindu Bali, segala sesuatu dapat dikaji secara lues dan fleksibel tanpa mengurangi arti maupun makna dari upacara atau kegiatan. Selain itu, arah pementasan tari sakral juga penting diperhatikan, yaitu jika sebuah tari sakral dipentasakan menghadap ke pelinggih (tempat suci), maka biasanya tarian tersebut dijadikan sebagai simbol untuk menyambut kedatangan atau turunnya para dewa-dewi dari langit ke bumi. Sedangkan jika arah pementasan tari sakral membelakangi pelinggih, berarti tarian itu merupakan simbol perwujudan dari para dewa-dewi yang dipuja atau bhatara-bhatari yang turun dari langit atau khayangan. Indikasi lainnya dari tari sakral juga dapat dilihat dari segi waktu pementasannya, yaitu dipentaskan tepat pada saat upacara berlangsung atau puncak upacara.

Dalam upacara Usaba Desa di Pura Pesamuhan Agung, Desa Nongan, Kecamatan Rendang, Kabupaten Karangasem tanggal 08 April 2019, area yang digunakan untuk mementaskan Tari Rejang Pala ialah Marga Agung atau badan Jalan Raya Nongan-Besakih, yang tepat berada di depan Pura Pesamuhan Agung. Di samping mempertimbangkan aspek nilai religius, penggunaan Marga Agung 

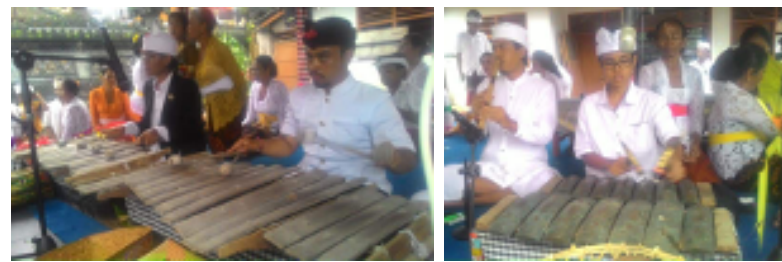

Gambar 12. Penabuh memainkan alat musik gambang untuk mengiringi Pementasan Tari Rejang Pala dalam upacara Usaba Desa di Pura Pesamuhan Agung, Desa Nongan, Karangasem (Foto: Adi Gunarta, 2019)

kurang lebih sepanjang 100 meter, juga didasarkan atas pertimbangan jumlah penari Rejang Pala yang terlibat pada pementasan perdana ini lebih dari 150 orang. Jika dipentaskan di jeroan pura pasti akan membuat para penari saling berdesak-desakan. Oleh karena letak Marga Agung (Jalan Raya Nongan-Besakih) sangat berdekatan dengan halaman utama pura, maka area tersebut dijadikan sebagai arena pementasan Tari Rejang Pala, agar seluruh penari dapat terakomodir serta dapat menari dengan baik. Perlu disampaikan pula bahwa, beberapa jenis upacara atau ritual yang ada di Bali juga menggunakan area Marga Agung sebagai tempat untuk melakukan persembahan dan biasanya dipusatkan di Catus Pata (perempatan agung) di masing-masing desa, seperti misalnya; upacara Tawur Agung Kesanga guna pembersihan Bhuana Agung (makrokosmos) dan Bhuana Alit (mikrokosmos) yang digelar setiap tilemsasih kesanga (bulan ke-9 dalam perhitungan kalender Bali/tahun caka) dan upacara nangluk merana (menolak bala/wabah) yang biasanya digelar setiap sasih kaenem (bulan ke-6 dalam perhitungan kalender Bali/tahun caka). Hal ini menandakan bahwa, setiap area yang digunakan oleh masyarakat Hindu Bali untuk melaksanakan prosesi ritual, selalu memiliki aspek nilai religius sesuai dengan konteks pelaksanaan upacara.

Tari Rejang Pala dipentaskan menghadap ke arah pelinggih (tempat suci). Secara lebih terperinci dapat dijelaskan bahwa, letak pelinggih di Pura Pesamuhan Agung Desa Nongan menghadap ke arah selatan, dan arah pementasan Tari Rejang Pala ialah mengahadap ke utara. Jika dikaji berdasarkan arah pementasannya, Tari Rejang Pala yang dipentaskan menghadap ke pelinggih merupakan sebagai simbol penyambutan para dewa-dewi yang turun dari khayangan untuk menyaksikan upacara Usaba Desa. Menjelang akhir pementasan, seluruh penari Rejang Pala membentuk satu barisan, kemudian bergerak menuju ke halaman depan pura (jaba pura) untuk bersiap mengakhiri tarian. Pada bagian akhir ini, secara khusus penari Rejang Daha secara satu persatu memasuki jeroan pura untuk melanjutkan prosesi mider atau mengelilingi pelinggih beserta sesaji sebanyak 3 kali putaran. Sedangkan penari Rejang Alit dan Rejang Lingsir tetap berada di jaba pura. Setelah prosesi mider di jeroan pura selesai, pementasan Tari Rejang Pala pun berakhir dengan melakukan persembahyangan bersama.

\section{Fungsi Tari Rejang Pala}

Setiap bentuk seni pertunjukan khususnya seni tari, pasti memiliki fungsi sesuai dengan teks dan konteks pementasannya. Soedarsono menjelaskan bahwa fungsi seni pertunjukan dikelompokkan menjadi dua, yakni fungsi primer dan fungsi sekunder. Secara garis besar seni pertunjukan memiliki tiga fungsi primer, yaitu (1) sebagai sarana ritual, (2) sebagai hiburan pribadi, (3) sebagai presentasi estetis (2002: 122-123). Berdasarkan teori di atas, dapat dijelaskan bahwa, Fungsi primer atau fungsi utama dari Tari Rejang Pala adalah sebagai sarana ritual dalam upacara Usaba Desa. Artinya, tarian ini merupakan sebuah sajian ritual yang dipentaskan untuk pelaksanaan upacara keagamaan Usaba Desa, ketika Ida Betara Dalem memasar di Pura Pesamuhan Agung, Desa Nongan, Karangasem. Tari Rejang Pala ini, merupakan tetamian (warisan) di Pura Balang Tamak, Desa Nongan, yang dahulunya (sebelum direkonstruksi) juga selalu dipentaskan untuk persembahan kepada Dewi Sri yang berstana di Pura Balang Tamak dalam upacara Usaba Pala, sebagai ungkapan rasa syukur atas keberhasilan panen. Selain itu, pementasan Tari Rejang Pala juga dimaksudkan sebagai sebuah sarana ritual untuk memohon keselamatan, kesuburan, dan kemakmuran bagi masyarakat Desa Nongan. Dengan memohon kesuburan, tentu harapannya ialah agar hasil-hasil panen berikutnya atau di masa-masa mendatang dapat semakin meningkat.

Dalam konteks upacara Usaba Desa, jika dicermati dan dimaknai dengan seksama, secara kasat mata anugerah kesuburan tersebut benar-benar hadir di tengah-tengah masyarakat Desa Nongan. Hal ini dapat dilihat dari peristiwa saat sebelum pementasan Tari Rejang Pala dimulai (ketika itu para penari tengah melakukan persiapan dan merapikan barisan), tiba-tiba hujan turun dengan perlahan dan semakin lebat. Meskipun demikian, para penari tetap melanjutkan persiapannya, hingga pementasan Tari Rejang Pala pun dimulai. Di bawah guyuran hujan tersebut, para penari melakukan tariannya dengan penuh hikmad, dilandasi rasa bakti dan ketulusan hati untuk ngayah (pengabdian secara tulus ikhlas untuk persembahan kepada Tuhan). Uniknya ialah ketika menjelang pementasan Tari Rejang Pala berakhir, hujan pun juga berangsur-angsur mereda dan sesaat setelah pementasan berakhir, matahari juga mulai kembali memancarkan sinarnya. Peristiwa tersebut mengisyaratkan suatu arti, yaitu hujan ialah pertanda dari kesuburun, serta merupakan simbol penghubung antara langit dan bumi. Setelah turun hujan, tanah akan menjadi subur, sehingga berbagai jenis tanaman yang bermanfaat bagi kehidupan masyarakat seperti padi, sayur-sayuran, buah-buahan serta yang lainnya akan dapat tumbuh dengan baik dan subur. Ini artinya, air hujan menjadi sumber dari kehidupan dan kesuburan. Seperti dijelaskan oleh Jakob Sumarjo bahwa, tanaman padi dapat terus hidup kalau ada "perkawinan" antara langit dan bumi. Langit mencurahkan hujannya kepada tanah yang kering. Dengan demikian langit itu "basah" dan bumi "kering". Basah itu asas perempuan dan 
kering asas laki-laki. Perkawinan keduanya akan menciptakan entitas ketiga, yakni kehidupan di muka bumi (2010: 243).

Selain memiliki fungsi primer (utama) sebagai sarana ritual, secara tidak langsung Tari Rejang Pala juga memiliki fungsi primer lainnya, yakni sebagai hiburan pribadi dan sebagai presentasi estetis, yang muncul pada saat berlangsungnya pementasan dalam upacara Usaba Desa. Fungsi sebagai hiburan pribadi dapat dilihat dari semangat kegembiraan dan antusias para penari yang ikut terlibat ngayah menarikan Tari Rejang Pala. Rasa suka cita atau kegembiraan juga terpancar dari wajah masyarakat Desa Nongan yang terlibat dan mempersiapkan pementasan Tari Rejang Pala, serta mengikuti seluruh rangkaian upacara. Semua itu mencerminkan bahwa, terdapat suatu kepuasan batin, rasasenang, rasa bangga, dan terhibur, baik di dalam diri para penari maupun masyarakat yang terlibat atau menonton. Sedangkan dalam fungsinya sebagai suatu bentuk presentasi estetis, Tari Rejang Pala menampilkan keindahan yang tersaji dalam setiap jalinan gerak tari yang anggun dan lembut, serta dibalut keindahan busana tari dengan segala keunikannya. Hal tersebut tentunya dapat memunculkan rasa decak kagum (kepuasan estetis) bagi setiap orangyang menonton. Terlebih lagi pada saat pementasan, para fotografer juga datang beramai-ramai untuk menyaksikan dan mengabadikan momen keindahan Tari Rejang Pala ke dalam sebuah foto, yang kelak dapat menjadi sebuah catatan peristiwa keindahan (sejarah). Di samping itu, Tari Rejang Pala juga mempunyai fungsi sekunder yang berkaitan dengan peranan atau fungsinya dalam kehidupan sosial masyarakat Desa Nongan. Adapun fungsi sekunder tersebut, adalah sebagai berikut.

\section{Tari Rejang Pala Sebagai Pengikat Solidaritas}

Keberadaan Tari Rejang Pala dapat menjadi pengikat rasa solidaritas di antara warga masyarakat Desa Nongan, yang tercermin dari semangat kerjasama dalam mempersiapkan segala perlengkapan upacara Usaba Desa dan juga pementasan Tari Rejang Pala. Dengan dilandasi spirit bakti dan rasa iklas untuk ngayah, setiap elemen masyarakat secara bersama-sama saling membantu mengerjakan seluruh persiapan sarana upacara, sehingga pelaksanaan upacara Usaba Desa berjalan lancar. Begitu juga dalam mempersiapkan pementasan Tari Rejang Pala, baik para penari, masyarakat, maupun panitia rekonstruksi, dengan penuh antusias bekerjasama mempersiapkan segala kebutuhan para penari, mulai dari mempersiapkan kostum tari sampai menghias gelungan rejang dilakukan dengan penuh suka cita.

\section{Tari Rejang Pala Sebagai Sarana Komunikasi}

Tari Rejang Pala yang dipentaskan dalam upacara Usaba Desa, berfungsi sebagai media komunikasi simbolis bagi masyarakat Desa Nongan untuk menyambut turunnya dewa-dewi ke bumi, yaitu menyambut (mamendak) Ida Betara Dalem Kupa dan Ida Betara Dalem Nongan pada prosesi memasar yang dilaksanakan di Pura Pesamuhan Agung. Dalam hal ini Tari Rejang Pala berperanan sebagai media komunikasi simbolis antara manusia dengan Tuhan. Berbagai bentuk sesajen, dipersembahkan oleh masyarakat sebagai ungkapan puji syukur dan terima kasih atas segala berkah yang telah dilimpahkan. Pementasan Tari Rejang Pala secara tidak langsung juga berdampak pada terjalinnya komunikasi verbal yang baik diantara warga masyarakat desa, dalam mempersiapkan segala perlengkapan sesajen dan pelaksanaan upacara. Selain itu, Tari Rejang Pala juga menjadi media komunikasi antar penari, dan juga antara penari dengan masyarakat penonton. Hal ini dapat dilihat dari terjalinnya suatu komunikasi verbal yang intens diantara para penari Rejang, maupun antara penari dengan masyarakat penonton serta mencerminkan rasa keakraban dan kebersamaan dalam persiapan dan pelaksanaan pementasan pada upacara Usaba Desa.

\section{SIMPULAN}

Tari Rejang Pala ialah sebuah tarian sakral bernilai religius yang keberadaannya berkaitan erat dengan Pura Balang Tamak dan cerita Pan Balang Tamak di Desa Nongan, Kecamatan Rendang, Kabupaten Karangasem. Dahulunya, tarian ini selalu dipentaskan pada upacara usaba pala, yakni sebuah upacara yang dilaksanakan di Pura Balang Tamak sebagai bentuk ungkapan rasa syukur kepada Dewi Sri atas keberhasilan panen. Setelah mengalami kemandekan atau tidak adanya regenerasi penari selama puluhan tahun, akhirnya tahun 2019 tarian ini berhasil direkonstruksi kembali oleh Ida Ayu Wayan Arya Satyani dan I Gusti Ngurah Sudibya. Tari Rejang Pala hasil rekonstruksi tahun 2019 makebah (pentas perdana) pada tanggal 8 April 2019 dalam upacara Usaba Desa. Usaba Desa merupakan suatu upacara yang dilaksanakan oleh masyarakat Desa Nongan setiap satu tahun sekali, guna menyambut ( $m a-$ mendak) Ida Betara Dalem (Ida betara Dalem Kupa dan Ida Betara Dalem Nongan) pada prosesi memasar atau paruman di Pura Pesamuhan Agung.

Bentuk Tari Rejang Pala disusun menggunakan gerak-gerak sederhana bernuansa ritual, khas rarejangan. Tari ini ditarikan oleh tiga kelompok penari berdasarkan klasifikasi umur dan makna filosofis, yaitu: (1) Rejang Alit merepresentasikan masa yang akan datang (nagata); (2) Rejang Daha merepresentasikan masa sekarang (wartamana, masa yang rentan yang harus dijaga disetiap tindak tanduknya); dan (3) Rejang Lingsir merepresentasikan masa lampau (atita, masa yang menjadi akar pijak, penguat, sebagaimana ibu, pertiwi). Pada saat makebah, jumlah penari melampaui 150 orang, menunjukkan antusias masyarakat. Jumlah penari inti (berdasarkan jumlah penari di Pura Balang Tamak) adalah 11 orang penari Rejang Daha. Koreografi masing-masing kelompok Rejang dibuat berbeda, namun gending gamelan yang digunakan sama. Gending tersebut berasal dari alunan gamelan kuna yang disebut Gambang. Struktur tariannya terdiri dari empat ba- 
gian, yaitu Mataki-taki, Masolah, Makideh/Pakideh, dan Panyawis. Ciri khas pada tata rias dan busananya adalah gelungan berhiaskan aneka ragam buah.

Fungsi primer dari Tari Rejang Pala, yaitu (1) sebagai sarana ritual untuk memohon keselamatan, kesuburan, dan kemakmuran bagi masyarakat Desa Nongan; (2) sebagai sarana hiburan pribadi, hal ini dapat dilihat dari semangat kegembiraan dan antusias para penari yang ikut terlibat ngayah menarikan Tari Rejang Pala; dan (3) sebagai presentasi estetis, Tari Rejang Pala menampilkan keindahan yang tersaji dalam setiap jalinan gerak tari yang anggun dan lembut, serta dibalut keindahan busana tari dengan segala keunikannya. Sedangkan fungsi sekundernya adalah sebagai pengikat solidaritas masyarakat Desa Nongan yang tercermin dari semangat kerjasama dalam mempersiapkan segala perlengkapan upacara Usaba Desa dan juga pementasan Tari Rejang Pala. Serta berfungsi sebagai sarana komunikasi, yakni media komunikasi simbolis bagi masyarakat Desa Nongan untuk menyambut turunnya dewa-dewi ke bumi dan sebagai media komunikasi verbal antar penari, dan juga antara penari dengan masyarakat penonton.

\section{DAFTAR RUJUKAN}

Bandem, I Made, dan Fredrik Eugene deBoer. 2004. Kaja dan Kelod: Tarian Bali Dalam Transisi. Yogyakarta: Badan Penerbit ISI Yogyakarta.

Dibia, I Wayan. 1999. Selayang Pandang Seni Pertunjukan Bali. Bandung: Masyarakat Seni Pertunjukan Indonesia dan Arti line.

Djelantik, A.A.M. 1990. Pengantar Dasar Estetika Jilid I: Estetika Instrumental. Denpasar: STSI Denpasar.

Mariasa, I Nengah. 2015. "Rejang Kuningan Di Kecamatan Abang Kabupaten Karangasem, Bali: Aspek Bentuk, Fungsi, dan Makna". Disertasi Pada Sekolah Pascasarjana Universitas Gajah Mada Yogyakarta.

Moleong, Lexy J. 2011.Metodologi Penelitian Kualitatif (Edisi Revisi). Bandung: PT. Remaja Rosdakarya.

Satyani, I. A. W. A., \& Gunarta, I. W. A. (2018). Rejang Di Pura Balang Tamak, Warisan Budaya Desa Nongan. Segara Widya : Jurnal Hasil Penelitian Dan Pengabdian Masyarakat Institut Seni Indonesia Denpasar, 6(1). https://jurnal.isi-dps.ac.id/index.php/segarawidya/article/view/354

Soedarsono, R.M. 2002. Seni Pertunjukan Indonesiadi Era Globalisasi. Yogyakarta: Gadjah Mada UniversityPress. Sumardjo, Jakob. 2010. Estetika Paradoks (Edisi Revisi). Bandung:Sunan Ambu Press.
Yudabakti, I Made dan I Wayan Watra. 2007. Filsafat Seni Sakral Dalam Kebudayaan Bali. Surabaya: Paramita. 